\title{
Toondoo comic in teaching speaking (a pre-experiment research)
}

\author{
Laila Wati $^{\left.{ }^{*}\right)}$, Siti Maysuroh ${ }^{1}$, Sri Wahyuni ${ }^{1}$, Ahmad Yusri $^{1}$, Nurul Hindri $^{1}$ \\ ${ }^{1}$ Universitas Hamzanwadi, Indonesia
}

\section{Article Info}

\section{Article history:}

Received Mar $09^{\text {th }}, 2021$

Revised Apr $17^{\text {th }}, 2021$

Accepted Apr $30^{\text {th }}, 2021$

\section{Keyword:}

Toondoo comic

Speaking ability

\section{Corresponding Author:}

Laila Wati,

Universitas Hamzanwadi

Email: ladyazzurry@gmail.com

\begin{abstract}
This research aims at finding the effectiveness of Toondoo Comic in teaching speaking at the second semester of Sendratasik Study Program of Hamzanwadi University in the academic year 2018-2019. This research was a pre experiment by using single group pre-test and post-test design. The population of the study was 47 students from A and B classes. The sample of the study was 17 students from class A. It was taken through purposive random sampling. A speaking test was used in collecting the data. The data collected were analyzed by using descriptive statistic, and paired sample t-test was used to test the hypothesis. It was performed using SPSS 22 for Windows. The result shows that the mean in the pre-test was 41.06 and was 60.71 in the post- test. Additionally, the hypothesis testing using paired sample t-test resulted significance (2-tailed) value level .000; it was lower than .05. This indicated that Toondoo comic was significantly effective in teaching speaking. Thus it is suggested that Tondoo comic is considered an alternative media in teaching and learning process.
\end{abstract}

(C) 2021 The Authors. Published by IICET

This is an open access article under the CC BY-NC-SA license

(https://creativecommons.org/licenses/by-nc-sa/4.0

\section{Introduction}

In learning a language, especially English as a foreign language in Indonesia (Mariani, 2016;), there are four language skills to be mastered; They are listening, speaking, reading, and writing. People usually learn to listen first, to speak, then to read, and finally to write. In addition, the other important elements such as pronunciation, intonation, grammar, vocabulary and spelling all play important roles in effective English production. They should be taught in any language learning to make learners use the target language communicatively.

Speaking is important (Yan, Goh, \& Zhou, 2018; Nurhayati, 2016) and a crucial part of foreign language learning because it is the way of communicating ideas and messages orally (Leong \& Ahmadi, 2017) with others. Speaking is the productive oral skill (Aydoğ an \& Akbarov, 2014; Zyoud, 2016; Aswad, 2017; Putri, Artini, \& Nitiasih, 2017; Parmawati, 2018) that consists of producing systematic verbal utterance to convey meaning. In short, speaking is called productive skill because it produces messages through oral production. Because this production is observable, productive speaking can be a measure of knowing a language.

Since speaking is an observable evidence of knowing a language, the ability to speak is crucially important for students who learn English as a foreign language. The ability to speak English clearly and efficiently contributes to the success of the learners in school and success later in every phase of life. Considerably, being able to speak English boost students' confident. To their peers, they look more special for their capability. It seems weird but it is true. This capability also provides them unique opportunity to communicate with a wider 
range of people. They can even make friends with people abroad. Additionally, in the future, in this more globalized world, capability of speaking English can give them competitive advantages. People who can speak English get better chance to seek for work in other countries especially in English speaking countries or countries with English as their second language.

Dealing with the importance of being able to speak a target language, speaking instruction needs to be focused more. Teachers should pay more attention to speaking instructions. However, it is not always easy to teach speaking. Speaking is one of the most difficult aspects for students to master ((Hape, 2018; Handayani \& Kumara, 2018). Many things should be considered in speaking. Speaking involves many things (Pimm, 2019; Rao, 2019; van Vlack, 2019) which includes awareness of register, genre, grammar, vocabulary, and pronunciation (Bigelow \& Smith, 2018). Thus, teachers have to find best ways to help students cope with speaking instruction.

As speaking is not easy for students, teachers need to vary their teaching technique and/or media to make the class more communicative, attractive, and contextual which facilitate students to speak and finally improve their speaking skill. Because the use of various media to support the teaching and learning process is important, Toondoo comic is offered as media in teaching speaking. Toondoo is a website which is used to create comic strips (Mufidah \& Solikhah, 2018). It has a number of pictures, characters, and scenery. Based on a previous study conducted by Subarkah in 2016, by using Toondoo, students are not only exposed to read comic strip but also to create their own comic strip (Subarkah, 2016).

Toondoo comic as media in teaching speaking can be very useful for an effective and joyful learning. Toondoo comic is appropriate to be used in speaking because of several reasons. First, Toondoo as an internet based learning nowadays has become life style, not only a need. Second, students are required to be familiar to the internet communication technology in language learning. Third, according to Dwi (2018), Toondoo lets students share their ideas, creativities, and imaginations into a project work and speak it orally.

Based on those strengths of Toondoo comic, it is necessary to investigate the effectiveness of Toondoo comic in teaching speaking. In order to cope with this purpose, a research question was proposed. The research question is "Is Toondoo comic effective in teaching speaking and how is the effectiveness of Toondoo comic in teaching speaking at the second semester of Sendratasik Study Program in Hamzanwadi University in the academic year 2018-2019?".

\section{Method}

This research is a pre-experiment research administering single group pre-test and post-test. It was conducted at Hamzanwadi University on May to July at the second semester of Sendratasik Study Program in the academic year 2018-2019. The second semester consisted of 47 students in two classes. 17 students were taken as the sample through purposive random sampling.

This research consisted of one variable that was students' speaking ability taught using Toondoo comic. Speaking is the process to utter words orally to communicate, to make a request, and to make a speech. Speaking is so much a part of daily life that people take. Speaking ability in this research refers to the ability of sharing something (a story) accurately and fluently based on the comic strip produced in a Toondoo comic. Toondoo is an online website which conceptualized and created by Jambav to create comic strips. Here, the students created their own comic, produced their own stories, then shared the stories orally.

In order to answer the research questions proposed, pre-test, treatment, and post-test were conducted. The pre-test was administered before the treatment to know the student's previous speaking ability. After conducting the pre-test, the treatment was conducted using Toondoo. At the first and second meeting, the material was focused on narrative taught using Toondoo. In the next meeting, the students in groups were led to create a comic via Toondoo. In this meeting, they discussed and decided the topic of their story then created their Toondoo comics. In the following meeting, they arranged their story based on the Toondoo comics made previously. In groups, they shared ideas and produced sentences reflecting the story in their comics.

Having finished all the treatment, the post-test was administered. This post-test was to see how effective Toondoo comic was in helping students to produce and share story orally. Here the students were asked to tell the story based on their Toondoo comic. They spoke within three to five minutes. The students' oral production was assed based on the accuracy of pronunciation, fluency, grammar, vocabulary, and comprehension. The rubric is described in Table 01. 
Table 1. Scoring rubric

\begin{tabular}{|c|c|c|c|}
\hline No & Elements & Score & Criteria \\
\hline \multirow[t]{5}{*}{1.} & \multirow{5}{*}{ Fluency } & 5 & Speak very fluently, native-like fluency. \\
\hline & & 4 & Speak less fluently due to few problems of vocabulary. \\
\hline & & 3 & $\begin{array}{l}\text { Occasionally have problems in speaking due to selection of words, so that } \\
\text { there are several pauses during speaking. }\end{array}$ \\
\hline & & 2 & Regular pauses and hesitancy. \\
\hline & & 1 & Very slow speaking due to serious language problems. \\
\hline \multirow[t]{5}{*}{2.} & \multirow[t]{5}{*}{ Grammar } & 5 & Very few mistakes without deducing the meaning of information. \\
\hline & & 4 & $\begin{array}{l}\text { Occasionally making mistakes, e.g. order of words, but the meaning can be } \\
\text { understood. }\end{array}$ \\
\hline & & 3 & Making several mistakes, thus repetition is necessary to strengthen meaning. \\
\hline & & 2 & Making many mistakes, so that meaning is unclear. \\
\hline & & 1 & Making regular mistakes so that it is difficult to understand. \\
\hline \multirow[t]{5}{*}{3.} & \multirow[t]{5}{*}{ Vocabulary } & 5 & Accurate selection of words, native speaker-like. \\
\hline & & 4 & Very few mistakes in word selection, but it does not deduce the meaning. \\
\hline & & 3 & $\begin{array}{l}\text { Occasionally uses inaccurate words, so that clarification of meaning is } \\
\text { necessary. }\end{array}$ \\
\hline & & 2 & Regular wrong uses of words which make meaning difficult to understand. \\
\hline & & 1 & Serious problems in using accurate words, so that it is unable to understand. \\
\hline \multirow[t]{5}{*}{4.} & \multirow[t]{5}{*}{ Pronunciation } & 5 & Accurate pronunciation with native-like accent. \\
\hline & & 4 & Accurate pronunciation with mother tongue accent. \\
\hline & & 3 & Good pronunciation with one or two mistakes. \\
\hline & & 2 & Having problems in pronunciation, thus it is difficult to comprehend. \\
\hline & & 1 & Having problems in pronunciation, thus it is unable to comprehend. \\
\hline \multirow[t]{5}{*}{5.} & \multirow[t]{5}{*}{ Comprehension } & 5 & $\begin{array}{l}\text { Very good understanding of the material so that the story could be expresses } \\
\text { nicely. }\end{array}$ \\
\hline & & 4 & $\begin{array}{l}\text { Good understanding of the material, but occasionally make repetitions in } \\
\text { expressing the story. }\end{array}$ \\
\hline & & 3 & $\begin{array}{l}\text { Having comprehension problems, but not serious and directly understand } \\
\text { after having some repetitions so that the story could be expressed. }\end{array}$ \\
\hline & & 2 & $\begin{array}{l}\text { Having difficulties to comprehend the material so that unable to express the } \\
\text { story. }\end{array}$ \\
\hline & & 1 & Unable to comprehend the material so that unable to express the story. \\
\hline
\end{tabular}

In analyzing the data, descriptive statistic was used to find out the mean score (M) and standard deviation (SD) of students score. To get mean score of pre-test and post-test, SPSS 22 for Windows was used. In testing the hypothesis, two statistics were required: normality and homogeneity. Normality testing was used to check whether the distribution of pre-test and post-test are normal or not. To know the data are normal or not, Shapiro-Wilk was performed using SPSS for windows. The data are considered normal if the values of the significance is higher than $(p)=0.05$. Additionally, homogeneity test was conducted to know that the data are homogeneous or not. The data are considered homogeneous if the values of the level significant is greater than $\mathrm{p}=.05$. Homogeneity test was performed by Lavene test by the help of SPSS 22 for Windows.

Based on the result of Shapiro-Wilk, it was found that the value of Shapiro Wilk in the pre-test was 0.32 and was 0.45 in the post-test. It proved that the data were normal because the value of the significance level in the pre-test and in the post-test was higher than the value of significance $(p)=0.05$. Besides, the homogeneity test showed that the data were homogenous because the Levene' test was 1.12 at $p=0.29$ which was higher than 0.05 .

Furthermore, to examine the effectiveness of Toondoo comic in teaching speaking, paired-sample t-test was used to process the data. The output of SPSS 22 shows the result of the procedure indicated that the null hypothesis is accepted or rejected. The hypothesis criteria are that if the mean score of pre-test is equal or lower than post-test; it means alternative hypothesis is accepted and the null hypothesis is rejected; If the mean score of pre-test is equal or higher than post-test, it means alternative hypothesis is rejected and the null hypothesis is accepted. The alternative hypothesis in this study was Toondoo comic is effective in teaching speaking at the second semester of Sendratasik Study Program in Hamzanwadi University in the academic year 2018-2019. 


\section{Results and Discussions}

After analyzing the collected data, it was found that the lowest score in the pre- test was 32 and the highest score was 50. In the post-test, the lowest score was 40 , and 76 was the highest score. Moreover, the standard deviation in the pre-test was 5.39 and in the post-test was 8.27. Additionally, the mean score in the pre-test was 41.06 and was 60.71 in the post-test. It means that the mean score in the post-test was higher than the mean score in the pre-test. This indicated that Toondoo comic was effective in teaching speaking.

After confirming that the collected data were normal and homogenous, paired-sample t-test was done to reveal the answer to the hypothesis. It was discovered that there was a significant difference in the mean score between the pre-test and the post-test in which $\mathrm{t}(\mathrm{df}=16)=18.52$ at $\mathrm{p}<0.000$. This score reflected that the hypothesis was accepted which means Toondoo comic was significantly effective in teaching speaking at the second semester of Sendratasik Study Program in Hamzanwadi University in the academic year 2018-2019.

In accordance to the result of this research, Toondoo is proven to be an effective medium in providing students with idea to speak. The presence of Toondoo strips as media is very accommodating. It is true that media play very important role (Ramdhani \& Muhammadiyah, 2015; Adeniregun, 2016). They can carry information to fulfil instructional objectives. Dealing with media, Harmer (2007, p. 148) states that any website has potential for English students, and Toondoo is one of them. Kirchhoff and Cook (in Dwi, 2018, p. 76) stated that Toondoo is a free, fully online comic creator that offers many options for comic strip creation through a user-friendly interface. In addition, Koenig and Olson (2010, p. 26) stated that Toondoo is a great way to assess comprehension of vocabulary, story lines, and main ideas for struggling students.

Additionally, Toondoo is proven to help provide students with idea to speak especially when pictures and texts are combined. It was observable that the students freely spoke their mind as the characters' talk in the comic strips provided for them. This is as Yilmas (2017) says that Toondoo gives a new way of learning. It is found in this research that the students were much accommodated for they could freely speak through creating their own comic strip in the Toondoo. What they created also helped them better develop their stories. As a result, they could perform better in telling their stories.

Toondoo is not only effective in providing ideas to speak, González states that the use of Toondoo can be beneficial for the students (González, 2016). In this research, Toondoo did not only affect the students' learning result, the comic strip in the Toondoo also helped improve the instructional process in the classroom. The colorful cartoons helped improve the students' motivation to learn and become more engaged to the story. They seemed to be so enthused with the cartoons especially when they chose their own characters and words for the characters' speak.

In a nutshell, Toondoo can encourage students to be more interested, motivated, and familiar to the internet communication technology in language learning. It makes teaching and learning process in the classroom be more active and various, so the students do not get bored in their learning. It also let students share their ideas, creativities, and imaginations into a work and share it orally.

\section{Conclusions}

Based on the result and discussion, it deduced that Toondoo comic strip is significantly effective in teaching speaking. Not only helping make better students' learning result but also improve the instructional process especially students' involvement. Tondoo also works students' creativity in creating comic strips especially and choosing appropriate words presenting their ideas. Thus, it is recommended that teachers use Toondoo comic as an additional media in teaching speaking. Hopefully, students can explore their ideas by making their own story and make students be more active, expressive, enthused, joyful, and pleased which at last enhance their speaking ability.

\section{References}

Adeniregun, G. S. (2016). Instructional media for effective teaching and learning. Zaria: Department of Business Administration, Ahmadu Bello University.

Aswad, M. (2017). Is It Truly Improvisational Exercise Push Students' Speaking Ability. Eduvelop, 1(1), 9-17.

Aydoğan, H., \& Akbarov, A. A. (2014). The four basic language skills, whole language \& intergrated skill approach in mainstream university classrooms in Turkey. Mediterranean Journal of Social Sciences, 5(9), 672.

Bigelow, M., \& Smith, G. (2018). Teaching Speaking in Non-Academic Contexts. The TESOL Encyclopedia of English Language Teaching, 1-6. 
González, A. M. V. (2016). Comic in ToonDoo and collaborative learning: A visual literacy resource to evidence vocabulary learning with emphasis in action verbs in an EFL group of seventh graders in a Cajicschool. Unpublished Thesis. Universidad Santo Tom.

Handayani, N. D., \& Kumara, D. G. A. G. (2018). The implementation of student team achievement division and picture series on improving the speaking skill of the 3rd grade students of cipta dharma elementary school in academic year 2016/2017. SHS Web of Conferences, 42, 103. EDP Sciences.

Hape, N. M. (2018). The Effect of Instagram to Students' Speaking at The Paredise English Course of Kampung Inggris in 2018. Artikel Skripsi Universitas Nusantara PGRI Kediri, 1-7.

Leong, L. A. I. M. E. I., \& Ahmadi, S. M. (2017). An Analysis Of Factors Influencing Learners'english Speaking Skill.

Mariani, N. (2016). Developing Students' Intelligent Character through Linguistic Politeness: The Case of English as a Foreign Language for Indonesian Students. English Language Teaching, 9(1), 101-106.

Mufidah, D. K., \& Solikhah, I. (2018). The Effectiveness of Toondoo to Enhance Students' Creative Writing (An Experimental Research at Tenth Grade of MAN Wonogiri in the Academic Year of 2017/2018). IAIN Surakarta.

Nurhayati, D. A. W. (2016). Using Local Drama in Writing and Speaking: EFL Learners' Creative Expresssion. Journal of English Language Teaching and Linguistics, 1(1), 51-77.

Parmawati, A. (2018). Using analytic teams technique to improve students'speaking skill. Edulitics (Education, Literature, And Linguistics) Journal, 3(2), 21-25.

Pimm, D. (2019). Routledge Revivals: Speaking Mathematically (1987): Communication in Mathematics Clasrooms (Vol. 4). Routledge.

Putri, N. L. P. N. S., Artini, L. P., \& Nitiasih, P. K. (2017). Project-based learning activities and EFL students' productive skills in English. Journal of Language Teaching and Research, 8(6), 1147-1155.

Ramdhani, M. A., \& Muhammadiyah, H. (2015). The criteria of learning media selection for character education in higher education.

Rao, P. S. (2019). The importance of speaking skills in English classrooms. Alford Council of International English \& Literature Journal (ACIELJ), 2(2), 6-18.

Subarkah, M. S. (2016). The Effectiveness of Toondoo and Picture Series to Enhance Students' Writing Skills in Term of Their Creativity (A Quasi Experimental Study at SMA N 2 Wonogiri). UNS (Sebelas Maret University).

Van Vlack, S. (2019). Teaching Listening and Speaking. Policy.

Yan, J., Goh, H. H., \& Zhou, H. X. (2018). Improving the Teaching of Chinese Speaking of Young Students from English-Speaking Families: Teacher's Professional Development. In Teaching Chinese Language in Singapore (pp. 65-82). Springer.

Zyoud, M. (2016). Theoretical perspective on how to develop speaking skill among university students. Pune Research Scholar an International Multidisciplinary Journal, 2(1), 1-10. 